\begin{tabular}{l|c|l}
\hline \hline Biological and & Vol. 6(1): 44-50, 2022 & $\begin{array}{l}\text { ISSN: 2002-6153 } \\
\text { Biol. Appl. Environ. Res. } \\
\text { www.baerj.com } \\
\text { editor@a baerj.com }\end{array}$ \\
\hline
\end{tabular}

\title{
A New Host and a New Locality for Aspidogaster limacoides Diesing, 1834 (Trematoda: Aspidogastridae) Infecting the Caspian Freshwater Turtle Mauremys caspica (Gmelin, 1774) in Basrah Province, Iraq
}

\author{
Salem A.M. Al-Daraji \\ Department of Marine Biology, Marine Science Centre, University of Basrah, Basrah, Iraq \\ *Corresponding author: aldarajisalem@gmail.com

\begin{abstract}
A total of 21 specimens of Aspidogaster limacoides Diesing, 1834 were detected from the small intestine of eight infected specimens of the Caspian freshwater turtle Mauremys caspica (Gmelin, 1774) captured from AlMashab River, northwest Basrah City. As the present parasite represents its first record in the turtle as a new host and in Basrah city as a new locality, a redescription, measurements and illustration are presented.
\end{abstract}

Keywords: Aspidogaster limacoides, Freshwater turtle, Mauremys caspica, Basrah, Iraq

\section{Introduction}

The subclass Aspidogastrea Faust \& Tang, 1936 represents a minor group among the class Trematoda Rudolphi, 1808. Zamparo \& Brooks (2003), in their systematic revision on the trematodes stated that subclass Aspidogastrea included four families of which the family Aspidogastridae includes three subfamilies, whereas the other three families (Aspidobothridae, Multicalycidae and Rugogastidae) include only a single genus each. According to WoRMS (2021), the family Aspidobothridae is accepted as Aspidogastridae.

Alves et al. (2015), in their checklist about the aspidogastrean trematodes of the world, which based on the comprehensive survey of the literature from 1826 until 2014, listed 61 valid species belonging to 13 genera within four families and two orders of aspidogastreans which infecting a total of 298 species of both vertebrate and invertebrate hosts.

The aspidogastrids have been described as parasites of a variety of aquatic organisms in both marine and freshwater environments. These flukes utilized a wide range of animals such as crustaceans, mollusks, fishes and reptiles as facultative or obligatory parasites (Rohde, 2002).

The aspidogastrean species can be easily distinguished from all their sisters, the digenetic parasites, by owing adhesive or holdfast ventral disc which containing a 
row of alveoli or so called suckerlets, which enable the parasite to fix itself to the host organs (Rohde, 2002).

Rohde (1972) mentioned that aspidogastrid parasites needs only a single host to complete their life cycles with no multiplicative larval stages. In addition, the same author, Rohde (1994) stated that Aspidogastrean have been regarded as having a low degree of host specificity. Gao et al. (2003) gives their own hypothesis concerning the presence of host specificity features between two different species of aspidogastrean parasites (A. conchicola Baer, 1827 and A. ijimai Kawamura, 1913) in infecting their definitive hosts. Chen et al. (2010), according to the results of their phylogenetic study, strongly supported Gao's et al. (2003) hypothesis. Lee et al. (2017) stated that none of the known aspidogastrean species has great economic or medical effects on their hosts. Diesing (1834) was the first author who described the aspidogastrean trematode A. limacoides without stating the site of samples collection.

Khalaf (1959) in his checklist of reptilians and amphibians of Iraq referred to presence of five species of turtles (Clemmys caspica caspica, Eretmocheyls imbricate bissa, Dermochelys coriacea schlegelii, Trionyx euphraticus and Testudo graeca ibera). Recently, Bosch (2003) in his introductory checklist of Iraqi herpetology referred to presence of nine species of turtles (Caretta caretta, Chelonia mydas, Eretmochelys imbricate bissa, Eretmochelys olivacea, Dermochelys coriacea schlegelii, Mauremys caspica caspica, M. c. siebenrocki. Rafetus euphraticus and Testudo graeca ibera).

It's well known that in southern parts of Iraq, especially in Basrah Province, the Caspian turtle or the hard shell freshwater turtle M. caspica (Gmelin,1774) (synonym C. caspica) and the soft shell turtle Rafetus euphraticus (Duadin, 1802) (synonym Trionyx euphraticus) are common turtles in the freshwater environments.

$M$. caspica is characterized by its medium size, tan to blackish colour with a hard oval shell in addition to a slight medial keel. Fritz \& Freytag (1993) referred to the widespread distribution of $M$. caspica from the Eastern parts of Europe to Turkey in addition to the Middle Eastern countries.

A great attention has been directed to turtles in recent years because they used in tradition Chinese medicine (Chen et al., 2009). Moreover, many cultures utilized turtles as a mean source of delicious meat. Roman \& Bowen (2000) stated that in recent years many turtle farms were established to raise the turtle meat production for human consumption.

To the best of my knowledge, there are only one study dealt with the bacterial infection of soft shell turtle Rafetus euphraticus (Bannai et al., 2017) in addition to seven studies concerned with the helminth fauna of Iraqi turtles: Hamad (1985), Molan \& Saeed (1990), Al-Hashimi (2006), Al-Barwari \& Saeed (2007), Mustafa (2014), Al-Emarah (2015), Hussain (2015) and Shubber et al. (2020). None of those studies referred to recording aspidogasrtian trematode from Iraqi turtles. 


\section{Materials and Methods}

Seventeen turtles were sampled, at the banks of the Al-Mashab River $\left(30^{\circ} 45^{\prime}\right.$ $31^{\circ} 00^{\prime} \mathrm{N}, 47^{\circ} 30^{\prime}-47^{\circ} 45^{\prime} \mathrm{E}$ ) which is connected with the southern parts of AlHammar Marsh. This river is situated at about $18 \mathrm{~km}$ north Basrah City. The collection was done from February to June 2018, by the aid of hand nets. The turtles were brought alive to the Laboratory of Parasitological Studies, at Hareer Station for Marsh Researches, Marine Science Centre, University of Basrah, for further examination.

Turtles were anesthetized and killed by using chloroform searching for their parasites. The alimentary canals were isolated, then dissected and examined under electro- dissecting microscope type WILD-M3B for any internal parasites.

The detected helminths were washed thoroughly by normal saline $(0.8 \%$ sol. $)$, fixed and preserved in AFA (acetic acid, formaldehyde and 80\% ethanol), stained with acetocarmine and dehydrated in graded alcohol series then mounted in D.P.X. according to Al-Daraji (1995). Turtles were identified according to Khalaf (1959) and updating nomenclature was according to WoRMS (2021) whereas, Yamaguti (1963) was used to identify the detected parasites. The data on prevalence and the mean intensity of infection were calculated as described by Bush et al. (1997). All measurements of the detected parasites are given in micrometers as a range with the mean.

\section{Results}

Seventeen specimens of the Caspian freshwater turtle M. caspica (Gmelin, 1774) were captured from Al-Mashab River and examined for their internal parasites. Eight of them were infected with the aspidogastrid parasite Aspidogaster limacoides Diesing, 1834. The description and measurements of this parasite are presented. Parasite taxonomy and its infection parameters are as follow:

Trematoda, Aspidogastridae: Aspidogaster limacoides Diesing, 1834 (Figure 1). Host: Mauremys caspica (Gmelin, 1774).

Locality: Al-Mashab River, north Basrah City, Iraq.

Location: Small intestine.

Prevalence and mean intensity of infection: $47 \%$ and 2.6, respectively.

Description and measurements based on eight mounted and well-pressed specimens.

The body of the live worm is thick with white reddish color and slightly elongated, muscular, tapering anteriorly and posteriorly, and measuring 3785-4066 (3925) in length and 1858-2031 (1985) in width and the maximum width of the parasites is observed at the region of reproductive organs. The oral sucker is absents and a simple terminal mouth is surrounded by a sucker-like muscular structure, located at the anterior margin of the body. The pharynx is large, well developed, muscular, ovoid in its shape, and measuring 326-384 (361) in length and 382-416 (397) in width, followed directly by the intestine. The intestine is simple, saccular 
with a single wide tubular caecum, covering large parts of the hindbody and reaching to near posterior extremity.

Testis is single, with ovoid shape and measuring 412-773 (705) in length and 384-697 (638) in width and located ventrolateraly at the postovarian level. The ovary is reniform in shape, pretesticular, at the equatorial level of the body and measuring 523-594 (571) in length and 248-296 (277) in width. Cirrus sac is large, enclosed in pyriform cirrus pouch, with narrow distal part and wide proximal part, measuring 264-596 (495) in length and 278-671 (599) in width and located transversely. Uterus is coiled, very long, occupying most of the body and fills with numerous eggs. Vitellaria are follicular, consist of two longitudinal portion with unequal length and occupying the hind body laterally on each side of intestine. Genital pore is located medioventrally anterior to the holdfast organ at the level of anterior end of the pharynx. Eggs numerous, with brownish color, relatively large in its size and measuring 71-79 (76) in length and 43-52 (47) in width. The excretory vesicle $\mathrm{v}$ - shaped and terminating with excretory pore at the posterior end of the body. The ventral holdfast disc bears four longitudinal rows of alveoli and marginal organs. The total number of the alveoli on the disk is 64-68.

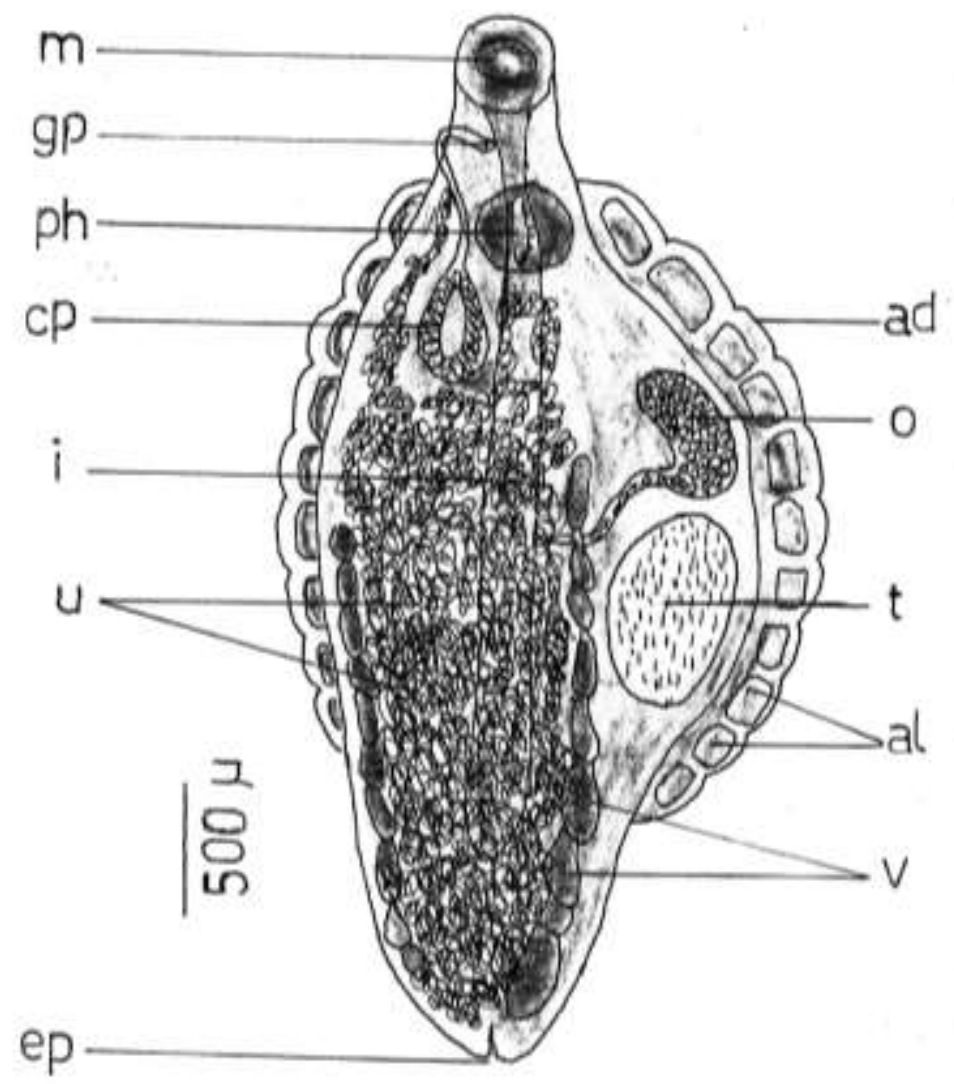

Figure 1: Aspidogaster limacoides ventral view. ad, adhesive disk; al, alveoli; cp, cirrus pouch; ep, excretory pore; gp, genital pore; i, intestine; m, mouth; o, ovary; ph, pharynx; t, testis; u, uterus; v, vitellaria. 


\section{Discussion}

Iraqi turtles have received a little attention from the biologists especially from the point of view of their parasitic fauna. Only eight references in this respect are known: Hamad (1985), Molan \& Saeed (1990), Al-Hashimi (2006), Al-Barwari \& Saeed (2007), Mustafa (2014), Al-Emarah (2015), Hussain (2015) and Shubber et al. (2020). Out of these studies, only the last two studies (Mustafa, 2014; AlEmarah, 2015) have been done in Basrah Province. Generally, among these eight previous studies, only three of them revealed the presence of three different species of trematodes belonging to the genus Telorchis (Digenea, Telorchiidae) infecting the same turtle M. caspica. These trematodes were T. cyclemidis (Tubangui, 1933) Wharton, 1940 by Al-Hashimi (2006) from Al-Ramadi City, Al-Anbar Province, T. stunkurdi Chandler, 1923 by Al-Barwari \& Saeed (2007) from different localities in north of Iraq and T. assula (Dujardin,1845) Dollfus, 1957 by Shubber et al. (2020) from Al-Diwaniya Province.

The description of A. limacoides which is recorded in the present study is slightly similar with that of Popiołek et al. (2007), but it is larger in most measurements. The large size of the present specimen of A. limacoides in contrast with its measurements in previous studies may be related to the large size of lumen of the small intestine of its present host (M. caspica).

So far, many authors; Yamaguti (1963), Bauer et al. (2002), Molloy et al. (1996), Laruelle et al. (2002), Gao et al. (2003) and Popiołek et al. (2007) stated that A. limacoides was recorded only from fish hosts. According to Mhaisen (2021), A. limacoides has 14 fish host species in Iraq. So, the present finding of this parasite in the small intestine of the Caspian freshwater turtles $M$. caspica captured in AlMashab River north Basrah City, Iraq, represents its first record in a turtle as a new host and in Basrah City as a new locality.

\section{References}

Al-Barwari, S. \& Saeed, I. (2007). On the helminth fauna of some Iraqi reptiles. Turk. Parazitol. Derg., 31(4): 330-336.

Al-Daraji, S.A.M. (1995). Taxonomical and ecological studies on the metazoan parasites of some marine fishes of Khor Al-Zubair estuary, north-west of the Arabian Gulf. Ph. D. Thesis, Coll. Agri., Univ. Basrah: 182 pp.

Al-Emarah, G.Y.A. (2015). Falcaustra heosemydis (Nematoda: Kathlaniidae) from Glemmys caspica turtles at Basrah City/ southern Iraq. J. Parasitol., Photon, 105: 207-211.

Al-Hashimi, S.F.A. (2006). Parasitic worms of alimentary canal of some reptile species in Al-Ramadi City. M. Sc. Thesis, Coll., Educ., Univ. Al-Anbar: 77 pp. (In Arabic).

Alves, P.V.; Vieira, F.M.; Santos, C.P.; Scholz, T. \& Luque, J.L. (2015). A checklist of the Aspidogastrea (Platyhelminthes: Trematoda) of the World. Zootaxa, 3918(3): 339-396. DOI:10.11646/zootaxa.3918.3.2.

Bannai, M.A.A.; Mohammad, E.T.; Shamary, A.J.; Al-Najjar K.A.; Al-Khwaja, F.M. \& Aldoghachi, M.A. (2017). A contribution and pathology of E. coli 
and Pseudomonas aeruginosa bacterial infection on soft shell turtle Rafetus euphraticus (Gray, 1864) East Hammar marshes, Iraq. Russian J. Parasitol., 40(2): 174-178.

Bauer, O.N.; Pugachev, O.N. \& Voronin, V.N. (2002). Study of parasites and diseases of sturgeons in Russia: A review. J. Appl. Ichthyol., 18: 420-429.

Bosch, H.A.J. In Den (2003). Iraqi herpetology: An introductory checklist. https://www.lacerta.de/AS/Bibliografie/BIB_12331.

Bush, A.O.; Lafferty, K.D.; Lotz, J.M. \& Shostak, A.W. (1997). Parasitology meets ecology on its own terms: Margolis et al. revisited. J. Parasitol., 83(4): 575583.

Chen, M.-X.; Zhang, L.-Q.; Wen, C.; Sun, J. \& Gao, Q. (2010). Phylogenetic relationship of species in the genus Aspidogaster (Aspidogastridae, Aspidogastrinae) in China as inferred from its rDNA sequences. Acta Hydrobiol. Sinica, 34(2): 312-316. DOI:10.3724/SP.J.1035.2009.00312.

Chen, T.-H.; Chang, H.-C. \& Lue, K.-Y. (2009). Unregulated trade in turtle shells for Chinese traditional medicine in East and Southeast Asia: The case of Taiwan. Chelonian Conserv. Biol., 8(1): 11-18. DOI:10.2744/CCB-0747.1.

Diesing, K.M. (1834). Aspidogaster limacoides, eine neue Art Binnenwurm. Medicinische Jahrbücher des k.k. österreichischen Staates 16 oder neueste Folge VII Band: 420-431.

Fritz, U. \& Freytag, O. (1993). The distribution of Mauremys in Asia Minor, and first record of $M$. caspica caspica (Gmelin, 1774) for the internally drained central basin of Anatolia (Testudines: Cryptodira: Bataguridae). Herpotozoa, 6: 97-103.

Gao, Q.; Nie, P. \& Yao, W.J. (2003). Scanning electron microscopy of Aspidogaster ijimai Kawamura, 1913 and A. conchicola Baer, 1827 (Aspidogastrea, Aspidogastridae) with reference to their fish definitive-host specificity. Parasitol. Res., 91(6): 439-443. DOI:10.1007/s00436-003-1002-7.

Hamad, N.R. (1985). Taxonomic study of digenetic trematodes of some vertebrates in some parts of northern Iraq. M. Sc. Thesis, Coll. Sci., Univ. Salahaddin: 88 pp.

Hussain, H.T. (2015). Survey of external parasites on the turtles Emydura macquarii present in fish breeding ponds in Al-Musaib Technical Institute. J. Kerbala Univ., Sci., 13(3): 46-49.

Khalaf, K.T. (1959). Reptiles of Iraq, with some notes on the amphibians. ArRabitta Press, Baghdad: vii + 96 pp.

Laruelle, F.; Molloy, D.P. \& Roitmann, V.A. (2002). Histological analysis of trematodes in Dreissena polymorpha: Their location, pathogenicity, and distinguishing morphological characteristics. J. Parasitol., 88(5): 856-863. DOI:10.1645/0022-3395(2002)088[0856:HAOTID]2.0.CO;2.

Lee, D.; Park, H.; Choe, S.; Kang, Y.; Jeon, H. \& Eom, K. (2017). New record of Aspidogaster ijimai Kawamura, 1913 (Trematoda: Aspidogastridae) from Cyprinus carpio in Korea. Kor. J. Parasitol., 55(5): 575-578. DOI:10.3347/ kjp.2017.55.5.575. 
Mhaisen, F.T. (2021). Index-catalogue of parasites and disease agents of fishes of Iraq (Unpublished: mhaisenft@ yahoo.co.uk).

Molan, A.L. \& Saeed, I.S. (1990). First record of five nematodes from Iraqi turtles. Bull. Iraq Nat. Hist. Mus., 8(3): 143-153.

Molloy, D.; Rortman, V.A. \& Shields, J. (1996). Survey of the parasites of zebra mussels (Bivalvia: Dreissenidae) in northwestern Russia, with comments of records of parasitism in Europe and North America. J. Helminthol. Soc. Washington, 63: 251-256.

Mustafa, F.A. (2014). The first record of nematode Chabaudinema americana (Diaz-Ungria, 1968) from turtles at Basrah City/ Iraq. J. Int. Acad. Res. Multidiscipl., 2(8): 423-428.

Popiołek, M.; Łuczyński, T. \& Jarnecki, H. (2007). The first record of Aspidogaster limacoides Diesing, 1834 (Aspidogastridae: Aspidogastrea) in Poland. Wiadomoeci Parazytol. 53(2): 139-141.

Rohde, K. (1972). The Aspidogastrea, especially Multicotyle purvisi Dawes, 1941. Adv. Parasitol. 10: 77-151. DOI:10.1016/S0065-308X(08)60173-6.

Rohde, K. (1994). The origins of parasitism in the Platyhelminthes. Int. J. Parasitol., 24(8): 1099-1115.

Rohde, K. (2002). Subclass Aspidogastrea Faust \& Tang, 1936. In Gibson, D.I.; Jones. A. \& Bray, R.A. (eds.). Keys to the Trematoda, vol. 1. CABI Publ., Wallingford: 5-14.

Roman, J. \& Bowen, B.W. (2000). The mock turtle syndrome: Genetic identification of turtle meat purchased in the south-eastern United States of America. Anim. Conserv., 3: 61-65.

Shubber, H.W.K.; Alwaaly, A.B.M. \& Mohammed, M.K. (2020). Intestinal helminth parasites of Caspian turtle Mauremys caspica (Gmelin, 1774) (Testudines, Geoemydidae) from Al-Diwaniya Province, Iraq. Ann. Trop. Med. Public Health, 23(12): 1-11. DOI:10.36295/ASRO.2020.231237.

WoRMS (2021). World Register of Marine Species at http:// www.marinespecies.org at VLIZ. (Accessed 24 July 2021).

Yamaguti, S. (1963). Systema Helminthum, vol. IV: Monogenea and Aspidocotylea. Intersci., New York: vii +699 pp.

Zamparo, D. \& Brooks, D.R. (2003). Phylogenetic systematic assessment of the Aspidobothrea (Platyhelminthes, Neodermata, Trematoda). J. Zool. Scr., 32(1): 83-93. DOI:10.1046/j.1463-6409.2003.00088.x. 